\title{
Analysis of suicide attempts among children hospitalised in the Department of Paediatrics in Zabrze in 2010-2016
}

\author{
Ewa Olszańska', Marta Turska', Sylwia Balcerowicz², Agata Chobot ${ }^{2}$, Majka Jaszczura², \\ Katarzyna Rojewska², Jarosław Kwiecień ${ }^{3}$
}

'Scientific Association of Paediatrics at the Department of Paediatrics, School of Medicine with the Division of Dentistry in Zabrze, Medical University of Silesia, Zabrze, Poland

${ }^{2}$ Professor Stanisław Szyszko Independent Public Clinical Hospital No. 1 in Zabrze, Medical University of Silesia, Zabrze, Poland

${ }^{3}$ Department of Paediatrics, School of Medicine with the Division of Dentistry in Zabrze, Medical University of Silesia, Zabrze, Poland

\section{ABSTRACT}

Introduction: Despite the current decline in the number of suicides, they are the second most common cause of death among children and adolescents. At the end of the 20th century, suicides represented about $10 \%$ of all causes of death of people up to 18 years old, but currently they reach up to $20 \%$. Over the years, the number of suicide attempts (SA) has also increased.

Aim of the study: The aim of the study was to analyse the cases of hospitalisation of children in the Department of Paediatrics of the Independent Public Clinical Hospital No. 1 in Zabrze (DP IPCH1) due to a suicide attempt.

Material and methods: Medical records of 87 patients hospitalised due to SA in the years 2010-2016 in the DP IPCH1 were retrospectively analysed.

Results: All children who were admitted to the hospital survived their suicide attempt. An almost 2.5-fold increase was observed in the numbers of hospitalisations in years 2010-2016. Up to $86.2 \%$ of the patients were girls. The average age in group was $15.2 \pm 1.4$ years. In order to commit suicide, children most often used medications (97.7\%). They regularly combined them with alcohol or self-harm. 3/4 of overdose incidents included prescription-only medicaments. Almost half of the patients previously showed self-destructive tendencies in the form of self-harm. For $78.2 \%$ of the responders it was the first suicide attempt. $40.7 \%$ of patients had pre-existing chronic diseases, and the next $20 \%$ were under the control of a psychologist or psychiatrist. After hospitalisation 11 children were transferred to a psychiatric ward for further treatment.

Conclusions: The increase of hospitalisations due to suicide attempts is disturbing. In this context, special attention should be given to children from risk groups such as: previous suicide attempts, chronically ill, addicted to alcohol or drugs, with impaired parent-child relationship, or with self-harm history.

\section{KEY WORDS:}

suicide attempt, self-harm, drug overdose.

\section{ADDRESS FOR CORRESPONDENCE:}

Ewa Olszańska, Scientific Association of Paediatrics at the Department of Paediatrics, School of Medicine with the Division of Dentistry in Zabrze, Medical University of Silesia, 13/15 3 Maja St., 41-800 Zabrze, Poland, e-mail: ewa.olszanska@o2.pl 


\section{INTRODUCTION}

Suicide attempts (SA) among children and adolescents are an important social subject, but one which is rarely tackled by Polish institutions, media, or educational programs. According to WHO data and Polish statistics, suicides are the second most frequent cause of death among people under 18 years old $[1,2]$. At the end of the $20^{\text {th }}$ century, about $10 \%$ of child deaths were a result of suicide, while in recent years the number of self-murders has increased to $20 \%$ of deaths of people up to 18 years old [2-5]. The increase of SA in the paediatric population is a disturbing trend $[2,6]$. Studies carried out in various countries show that up to $10 \%$ of adolescents attempt to self-harm or self-poison for suicide purposes $[7,8]$. In the global population the $\mathrm{WHO}$ distinguishes five different groups of risk factors for committing suicide, related to: healthcare system, society, community, interpersonal relations, and individual [1]. For children and adolescents, the most important risks factors are: previous SA, mental illness, or abnormalities in the child-parent relationship [9-11].

\section{AIM OF THE STUDY}

The aim of the study was to analyse the cases of children's hospitalisation in the Department of Paediatrics of the Independent Public Clinical Hospital No. 1 in Zabrze (DP IPCH1) due to a suicide attempt in the years 20102016, with particular attention paid to suicide risk factors.

\section{MATERIAL AND METHODS}

We analysed the medical records of patients hospitalised in the years 2010-2016 in DP IPCH1. The criteria of inclusion in the study were conscious self-mutilation or the use of drugs or other substances for suicidal purposes. The hospital computer system was searched for diagnosis on discharge according to the International Classification of

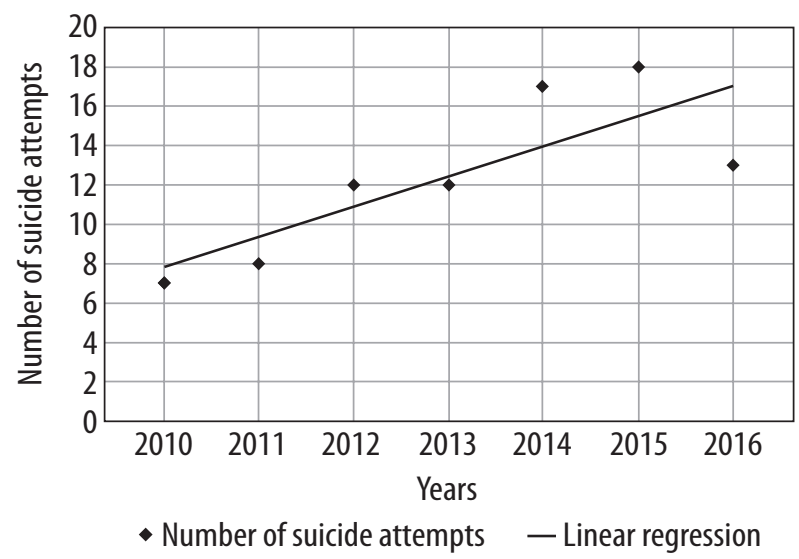

FIGURE 1. Number of suicide attempts among children hospitalised in the Department of Paediatrics of the Independent Public Clinical Hospital No. 1 in Zabrze in subsequent years in the period 2010-2016
Diseases and Related Health Problems IDC 10 (X60-X84) - "Intentional self-harm". A psychological or psychiatric consultation stating suicidal intention was also required.

Finally, 87 cases were qualified for the analysis. Among the patients $86.2 \%$ were girls and $13.8 \%$ were boys. The youngest child was 11 and the oldest was almost 18 years old. The average age was $15.2 \pm 1.4$ years for the whole group (median 15) and was comparable for both sexes (girls $15.2 \pm 1.4$ years, boys $15.2 \pm 0.9$ years).

Data were statistically analysed using STATISTICA 12.5 (StatSoft, Krakow, Poland). The mean values, standard deviations, median, minimum, and maximum were calculated. In order to compare quantitative variables with distributions close to normal, Student's t-test was used. For variables with a non-normal distribution, the Mann-Whitney U test was used to compare two independent groups, and for correlation assign Spearman rank correlation was utilised. Also, multiplied regression was applied. The statistical significance was set at $p<0.05$.

\section{RESULTS}

All children admitted to DP IPCH1 survived their suicide attempt. The analysis showed an increasing number of SAs in the study group (Table 1 ). These changes are statistically significant $\left(p<0.05, R^{2}=0.65\right)$ (Fig. 1). Despite the decrease in the number of hospitalisations in the ward (Table 1), the correlation between the number of suicide attempts and hospitalisations in the Department of Paediatrics is not statistically significant $(p>0.05)$.

The most common method of attempting suicide was drug overdose (97.7\%). Two patients took narcotics for suicidal purposes, and one child tried self-poisoning with gas. In $16.1 \%$ of cases, children combined drug overdose with alcohol, in $11.5 \%$ - with self-harm, and in one case with flooding and gas poisoning.

Analysing the used drugs more closely, 25.6\% of children used non-prescription specifics (over the counterOTC), and the remaining $74.4 \%$ of cases used also legally prescribed drugs. The most commonly used medicines were neuroleptics or antidepressants $(28.6 \%)$, followed by: paracetamol (25\%), non-steroidal anti-inflammatory drugs (NSAIDs, 23.8\%), and sedative-hypnotics (21.4\%). Among other substances used by children the following were found: vitamins, antibiotics, anticonvulsants, and antitussives. On average, children combined two groups of drugs; however, $22.6 \%$ of the patients used three or more different substances. The average number of pills taken for suicide purposes was 29 (ranging from 3 to 150).

An important issue is the availability of such a large number of drugs. According to the information contained in medical histories and the specialist consultations, the children mainly used medicines available at home. In some cases, these were drugs that patients used for their chronic diseases. However, most of children used drugs from the home medicine cabinet, used by other family 
members such as parents or grandparents. In one case, the patient collected drugs available without a prescription himself for several days before the SA.

Before SA, almost half of the respondents revealed auto-aggressive behaviours (44.8\%), mainly in the form of self-injury. For the great majority, it was the first suicide attempt; however, in $21.2 \%$ of cases it was the second or subsequent incident.

A history of psychological or psychiatric care before SA was found in $31.4 \%$ of patients. In $20.2 \%$ of cases, addiction to alcohol or cigarettes was found in the medical history or psychological or psychiatric consultation. Family problems occurred in most of the analysed cases, as detailed in Table 2.

$40.2 \%$ of children had pre-existing chronic diseases. $20.7 \%$ of patients suffered from mental illness (such as schizophrenia, anorexia, bulimia, depression) or behavioural and emotional disorders. A further $17.2 \%$ had typical somatic diseases: type 1 diabetes, hearing loss, psoriasis, asthma, or cystic fibrosis. Those two types of disorders occurred simultaneously in two patients. Chronic patients statistically significantly more frequently used anticonvulsants and neuroleptics compared with healthy ones $(p<0.05)$.

In the study group, approximately $17 \%$ of children were not in the risk groups for suicide attempts. The patients did not have chronic diseases, addictions, and no family history of mental illnesses or abnormalities in the child-parent relationship. For these patients it was also the first SA.

Every patient who was admitted to DP IPCH1 due to suicide attempt was consulted by a psychologist and/or psychiatrist. According to information obtained during those consultations, the most common motive for attempting suicide were family problems $(32.2 \%)$, such as parents' divorce or separation, an argument with family members, or harassment from the father. All known reasons of SA are presented and summarised in Table 3.

Eleven children (12.6\%) were referred to further treatment in the psychiatric ward, and in next three cases - the parents refused to continue hospitalisation of the child in such a unit.

\section{DISCUSSION}

Suicide attempts are an important topic in the paediatric population, especially among teenage girls. Our study was dominated by the young female population hospitalised in the Department of Paediatrics due to SA. Such a significant female predominance was also noted in other studies $[6-8,12-15]$. The latest study published by Plemmons et al. gives a much smaller percentage of girls taking SA compared to our study (64.4\% vs. $86.2 \%)$, although they continue to represent the vast majority of suicide attempts [6]. However, researchers suggest that boys often make more effective SAs $[15,16]$.
TABLE 1. Number of suicide attempts and hospitalisations in the Department of Paediatrics of the Independent Public Clinical Hospital No. 1 in Zabrze in subsequent years in the period 2010-2016

\begin{tabular}{|l|c|c|}
\hline Year & $\begin{array}{c}\text { Number of suicide } \\
\text { attempts }\end{array}$ & $\begin{array}{c}\text { Number } \\
\text { of hospitalisations }\end{array}$ \\
\hline 2010 & 7 & 2194 \\
\hline 2011 & 8 & 1919 \\
\hline 2012 & 12 & 1674 \\
\hline 2013 & 12 & 1124 \\
\hline 2014 & 17 & 1145 \\
\hline 2015 & 18 & 1167 \\
\hline 2016 & 13 & 1118 \\
\hline
\end{tabular}

TABLE 2. Family problems concerning among children hospitalised in the Department of Paediatrics of the Independent Public Clinical Hospital No. 1 in Zabrze after attempted suicide in the years 2010-2016

\begin{tabular}{|l|c|}
\hline Family situation & Percentage of patients \\
\hline Broken family & 32.2 \\
\hline Living in orphanage & 8.1 \\
\hline Mental diseases in the family & 13.3 \\
\hline Alcoholism in the family & 15.1 \\
\hline
\end{tabular}

TABLE 3. Causes of suicide attempts among children hospitalised for this reason in the Department of Paediatrics of the Independent Public Clinical Hospital No. 1 in Zabrze in the years 2010-2016

\begin{tabular}{|l|c|}
\hline Cause of suicide attempts & Percentage of patients \\
\hline Family issues & 32.2 \\
\hline Unrequited love & 11.5 \\
\hline School problems & 11.5 \\
\hline Chronic disease & 6.9 \\
\hline $\begin{array}{l}\text { No data or the child did not want } \\
\text { to give a reason }\end{array}$ & 37.9 \\
\hline
\end{tabular}

The age of the respondents is alarming - the youngest patient in our analysed group was 11 years old and the average age was $15.18 \pm 1.4$ years. In the literature 15-17-year-old children dominate in SAs [6]. However, the researchers also observed that the youngest patients were 5 to 11 years old [6.] In addition, a study conducted by Polish scientists indicates that the largest group of children attempting suicide are girls aged 14-17 years, which suggests that they should be covered by special prevention [17].

Another important and disturbing observation is the increasing number of suicide attempts among children and adolescents. According to the literature, deaths due to suicide are the second leading cause of mortality in the age group 5-19 years $[2,6]$. Police statistics show that the number of suicides in Poland in years 1999-2017 among 
teenagers aged $13-18$ years decreased from 251 to 115 [3-5]. In the younger age group (7-12 years) fatal SAs are rare, and their frequency has decreased: in $1999-$ 11 cases, in 2017 - 1 case [3-5]. Reducing the number of suicides is not tantamount to reducing the number of suicide attempts, according to a study conducted in the USA, where a two-fold increase in the number of hospitalisations due to SA was stated [6].

Our observation shows that among the methods of $\mathrm{SA}$, the most common was an attempt to overdose on drugs, which is consistent with the observations obtained by other authors $[12,17]$. According to Gmitrowicz, sedatives are the most frequently chosen drugs for suicidal purposes [12]. However, in our study they were fourth in order. It is also worth noting that in the vast majority of cases, among medicines were also those available on prescription, and less than $1 / 3$ of the patients admitted to only using OTC drugs. Nevertheless, an international study based on a survey shows that self-harm is the most common form of suicidal behaviour [8]. However, cases of drug overdose are more frequently reported and hospitalised [8]. According to available data, children and adolescents most often commit suicide by hanging [16]. Those discrepancies may result from directing such patients to other units (such as surgical or orthopaedic departments) and from overall survival after SA using medications overdose compared with hanging.

According to the research, there are many potential risk factors for a suicide attempt [1,9-11]. The WHO separates risk factors into five groups: healthcare system, society, community, interpersonal relations, and individual [1]. The major individual factors are previous attempts, and a history of mental and chronic diseases; however, the community factors, such as parent-child relations and mental illness and suicides in the family, also play an important role in potential suicide attempts [1,9-11].

A significant observation was the amount of the multiple suicides. In the studied centre $21.2 \%$ of the respondents had history of two or more suicide attempts. It is also stated that almost $27 \%$ of children decide on another SA $[18,19]$. According to the WHO previous suicide attempt is the most important risk factor for suicide [1].

In the study group, nearly half of the patients had a previous history of self-harm. It is worth noting that only a small percentage of patients with self-harm are hospitalised for that reason; the vast majority are not even reported to the doctor [20]. Studies show that on average fewer than $7 \%$ of cases of self-harm and $23 \%$ of drug overdoses are admitted to the hospital [7].

Family environment is major risk factor for suicide attempt [1, 21-24]. Among the others, the most important is the lack of security in the home environment [21]. It may be the effect of both physical and emotional deprivation of caretakers close to the child. A study conducted by Makary-Studzińska revealed that the most frequent reason for SA in youths was the feeling of emotional re- jection by their parents (57\%) [22]. As important motives, the respondents also indicated conflicts with their fathers or a parent's death [22]. According to Shaffer et al., in the risk group of SA are children who have disturbed relationships with their parents due to: their divorce, domestic violence, or alcohol abuse in the home environment [9]. Our analysis of the family situation of children who attempted suicide showed that in $15 \%$ of questioned families, at least one parent was abusing alcohol. However, in a study conducted in Łódź on a group of 119 children treated psychiatrically after a suicide attempt, the authors did not show a connection between alcohol dependence syndrome for one or both parents and patients' SAs [25]. Another aspect of the family system was found in a publication from 2013 [23]. There was a close connection between SA and a disturbed parent-child relationship due to lack of care as well as over-protectiveness [23]. In our study over $30 \%$ of children revealed family issues as the most important reason for their suicide attempt.

Although the dysfunctionality of the family system increases the risk of suicidal behaviour, this is not a vital factor. Currently, an increasing number of suicide attempts in the group of adolescents was found, from all backgrounds and social strata, including family systems in which no significant functional difficulties were observed [22].

The next major factors are connected with community and individual traits. In Makary-Studzińska’s study over $55 \%$ of patients indicated difficulties in peer relationships, $44 \%$ poor progress in learning, and $21 \%$ conflicts with teachers as significant for their suicidal behaviour [22]. Among personality traits associated with suicidal behaviours, the authors include: low self-esteem, introversion, neuroticism, impulsiveness, passivity, dependence, anxiety, and social maladjustment [26]. Alcohol abuse is also one of the individual risk factors for suicide attempts [1]. $20 \%$ of our patients were addicted to alcohol. The research indicates the relationship between episodic, excessive alcohol consumption by young people and attempting suicide $[1,27]$. Such behaviour increases the risk of committing suicide by 2.6 times [27]. Also, another scientific study proves that consumption of alcohol defined by the drinking person as "small" increases the risk of SA by up to three times [28]. According to the literature, almost $20 \%$ of respondents were under the influence of alcohol while attempting suicide [8]. In our study it was about $16 \%$ of children.

Also, an important group of patients are those with no risk factors before SA. A study on suicide attempts indicated that there are a group of patients who did not show suicidal behaviours before their SA and did not talk about their purposes [29]. However, other authors showed that in as many as $75 \%$ of cases, the respondents claimed that someone knew about their suicidal intentions [8].

Among the motives of SA, our analysis revealed such reasons as: family conflicts, school failures, unhappy love, 
and lack of social acceptance. These results are consistent with other publications $[11,24]$. In the Gmitrowicz study, the respondents described the lack of meaning in life as the most frequent psychological motivation for a suicide attempt, followed by problems at school (30\%), difficult family situation $(24.9 \%)$, loss of a loved one (22.9\%), and a fascination with death (19\%) [30].

\section{CONCLUSIONS}

Despite the decrease in the number of suicides, we observed a significant increase in the number of SAs that were the cause of hospitalisation in the study group. A particularly large group of patients were girls aged 14-16 years. The most common method of attempting suicide was a drug overdose, mainly prescription drugs such as neuroleptics and antidepressants. Paracetamol and non-steroidal anti-inflammatory drugs were popular among OTC medications. A significant number of children were at risk of suicide attempt. In the above context, special care should be given to children: after previous SA, chronically ill, with addictions, with parent-child relationship disorders, and with self-harm history. There should be attempts to limit the availability of larger amount of drugs in the home, especially with children who are chronically ill or from risk groups.

\section{DISCLOSURE}

The authors declare no conflict of interest.

\section{REFERENCES}

1. World Health Organization. Preventing suicide: a global imperative. World Health Organization, 2014.

2. Główny Urząd Statystyczny. Dzieci w Polsce w 2014 roku. Warszawa 2015: 13-14.

3. Zamachy samobójcze zakończone zgonem - grupa wiekowa, dzień tygodnia - 1999-2012 http://statystyka.policja.pl/st/wybrane-statystyki/ zamachy-samobojcze/122325,Zamachy-samobojcze-od-1999-do-2012. html (access: 01.06.2018).

4. Zamachy samobójcze zakończone zgonem - grupa wiekowa, dzień tygodnia - 2013-2016 http://statystyka.policja.pl/st/wybrane-statystyki/ zamachy-samobojcze/122324,Zamachy-samobojcze-od-2013-do-2016. html (access: 01.06.2018).

5. Zamachy samobójcze zakończone zgonem - grupa wiekowa, dzień tygodnia - $2017 \mathrm{http}: / /$ statystyka.policja.pl/st/wybrane-statystyki/ zamachy-samobojcze/63803,Zamachy-samobojcze-od-2017-roku.html (access: 01.06.2018)

6. Plemmons G, Hall M, Doupnik S, et al. Hospitalization for Suicide Ideation or Attempt: 2008-2015. Pediatrics 2018; 6: e20172426.

7. Hawton K, Rodham K, Evans E, Weatherall R. Deliberate self-harm in adolescents: self-report survey in schools in England. BMJ 2002; 325: 1207-1211.

8. Madge N, Hewitt A, Hawton K, et al. Deliberate self-harm within an international community sample of young people: comparative findings from the Child and Adolescent Self-harm in Europe (CASE) Study. J Child Psychol Psychiatry 2008; 49: 667-677.
9. Shaffer D, Pfeffer CR. Practice parameter for assessment and treatment of children and adolescents with suicidal behavior. J Am Acad Child Adolesc Psychiatry 2001; 40 (Suppl 7): 24-51.

10. Bazrafshan MR, Sharif F, Molazem Z, Mani A. Exploring the risk factors contributing to suicide attempt among adolescents: A qualitative study. Iran J Nurs Midwifery Res 2016; 21: 93-99.

11. Cekiera C. Psychologiczne i aksjologiczne aspekty samobójstw. Suicydologia 2005; 1: 21-32.

12. Gmitrowicz A. Społeczne i psychiatryczne uwarunkowania prób samobójczych u młodzieży. Post Psychiatr Neurol 1999; 8: 459-463.

13. Gmitrowicz A, Rabe-Jabłońska J, Warzocha D. Rozpoznania psychiatryczne u młodocianych po wielokrotnych i pojedynczych próbach samobójczych. Post Psychiatr Neurol 1998; 7: 419-428.

14. Jarosz M. Samobójstwa. PWN, Warszawa 1997.

15. Brodniak W, Podstawowe problemy prewencji samobójstw dzieci i młodzieży. Wprowadzenie. Fraszka Edukacyjna, Warszawa 2007: 7-12.

16. Napieralska E, Kułaga Z, Gurzkowska B, et al. Epidemiologia zgonów dzieci i młodzieży z powodu samobójstw w Polsce w latach 1999-2006. Probl Hig Epidemiol 2010; 91: 92-98.

17. Kierus K, Nawrocka B, Białokoz-Kalinowska I, et al. Zatrucia przypadkowe i celowe w latach 2006-2010 jako przyczyna hospitalizacji pacjentów w Klinice Pediatrii i Zaburzeń Rozwoju Dzieci i Młodzieży Uniwersyteckiego Dziecięcego Szpitala Klinicznego w Białymstoku. Pediatr Med Rodz 2011; 7: 361-365.

18. Hawton K, Bergen H, Kapur N, et al. Repetition of self-harm and suicide following self-harm in children and adolescents: findings from the Multicentre Study of Self-harm in England. J Child Psychol Psychiatry 2012; 53: 1212-1219.

19. Rosenbaum Asarnow J, Berk M, Zhang L, et al. Emergency department youth patients with suicidal ideation or attempts: predicting suicide attempts through 18 months of follow-up. Suicide Life Threat Behav 2017; 7: 551-566.

20. Hawton K, Saunders KEA, O'Connor RC. Self-harm and suicide in adolescents. Lancet 2012; 379: 2373-2382.

21. Malicka-Gorzelańczyk H. Psychospołeczne uwarunkowania zamachów samobójczych dzieci i młodzieży. In: Polska młodzież-zagrożenia, zaburzenia w aktualnej rzeczywistości społecznej, Sołtysiak T, Karwowska M (eds.). Wydawnictwo UKW, Bydgoszcz 2001.

22. Makara-Studzińska M. Przyczyny prób samobójczych u młodzieży w wieku 14-18 lat. Psychiatria 2013; 10: 76-83.

23. Goschin S, Briggs J, Blanco-Lutzen S, et al. Parental affectionless control and suicidality. J Affect Dis 2013; 151: 1-6.

24. Bazrafshan MR, Sharif F, Molazem Z, et al. Exploring the risk factors contributing to suicide attempt among adolescents: A qualitative study. Iran J Nurs Midwifery Res 2016; 21: 93-99.

25. Krajewska K, Florkowski A, Gmitrowicz A. Związek zespołu zależności alkoholowej rodziców z występowaniem prób samobójczych wśród nastoletnich pacjentów hospitalizowanych psychiatrycznie. Psychiatr Psychol Klin 2014; 14: 196-201.

26. Sumiła A, Sulska E. Zachowania samobójcze u pacjentów hospitalizowanych psychiatrycznie na oddziale młodzieżowym. Psychiatria 2006; 3: $128-132$.

27. Aseltine RH, Schilling EA, James A, et al. Age variability in the association between heavy episodic drinking and adolescent suicide attempts: findings from a large-scale, school-based screening program. J Am Acad Child Adolescent Psychiatry 2009; 48: 262-270.

28. Schilling EA, Aseltine RH, Glanovsky JL. Adolescent alcohol use, suicidal ideation, and suicide attempts. J Adolesc Health 2009; 44: 335-341.

29. Horesh N, Zalsman G, Apter A. Suicidal behavior and self-disclosure inadolescent psychiatric inpatients. J Nerv Ment Dis 2004; 192: 837-842.

30. Gmitrowicz A, Dubla W. Zachowania samobójcze w reprezentatywnej grupie młodzieży z terenu Łodzi. Psychiatr Psychol Klin 2001; 3: 236-243. 